\title{
Reproductive health and pregnancy outcomes among French gulf
} war veterans

\author{
Catherine Verret*1,2, Mathe-Aline Jutand ${ }^{3}$, Catherine De Vigan ${ }^{4,5}$, \\ Marion Bégassat ${ }^{3}$, Lynda Bensefa-Colas, Patrick Brochard ${ }^{1}$ and \\ Roger Salamon ${ }^{3}$
}

\author{
Address: ${ }^{1}$ Laboratory of Occupational and Environmental Health, Victor Segalen Bordeaux 2 University, Bordeaux, France, ${ }^{2}$ Département \\ d'Epidémiologie et de Santé Publique Nord, Ecole du Val-de Grâce, Paris, France, ${ }^{3}$ Epidemiology, Public Health and Development (INSERM \\ U593), Victor Segalen University Bordeaux 2, Bordeaux, France, ${ }^{4}$ Paris Registry of Congenital Malformations, INSERM UMR S149, IFR 69 Villejuif, \\ France, Université Pierre et Marie Curie 6, Paris, France and ${ }^{5}$ Clinic of Occupational Diseases, Cochin Hospital, AP-HP, Paris 5 University, Paris, \\ France \\ Email: Catherine Verret* - catherine.verret@wanadoo.fr; Mathe-Aline Jutand - marthe-aline.jutand@isped.u-bordeaux2.fr; Catherine De \\ Vigan - devigan@vjf.inserm.fr; Marion Bégassat - marion.begassat@isped.u-bordeaux2.fr; Lynda Bensefa-Colas - lynda.bensefa@cch.ap-hop- \\ paris.fr; Patrick Brochard - patrick.brochard@chu-bordeaux.fr; Roger Salamon - roger.salamon@isped.u-bordeaux2.fr \\ * Corresponding author
}

Published: 28 April 2008

BMC Public Health 2008, 8:141 doi:10.1 |86/|47|-2458-8-141

This article is available from: http://www.biomedcentral.com/I47/-2458/8//4I

(C) 2008 Verret et al; licensee BioMed Central Ltd.

This is an Open Access article distributed under the terms of the Creative Commons Attribution License (http://creativecommons.org/licenses/by/2.0), which permits unrestricted use, distribution, and reproduction in any medium, provided the original work is properly cited.
Received: 12 July 2007
Accepted: 28 April 2008

\begin{abstract}
Background: Since 1993, many studies on the health of Persian Gulf War veterans (PGWVs) have been undertaken. Some authors have concluded that an association exists between Gulf War service and reported infertility or miscarriage, but that effects on PGWV's children were limited.

The present study's objective was to describe the reproductive outcome and health of offspring of French Gulf War veterans.

Methods: The French Study on the Persian Gulf War (PGW) and its Health Consequences is an exhaustive cross-sectional study on all French PGWVs conducted from 2002 to 2004 . Data were collected by postal selfadministered questionnaire. A case-control study nested in this cohort was conducted to evaluate the link between PGW-related exposures and fathering a child with a birth defect.

Results: In the present study, $9 \%$ of the 5,666 Gulf veterans who participated reported fertility disorders, and $12 \%$ of male veterans reported at least one miscarriage among their partners after the PGW. Overall, $4.2 \%$ of fathers reported at least one child with a birth defect conceived after the mission. No PGW-related exposure was associated with any birth defect in children fathered after the PGW mission. Concerning the reported health of children born after the PGW, I.0\% of children presented a pre-term delivery and $2.7 \%$ a birth defect. The main birth defects reported were musculoskeletal malformations $(0.5 \%)$ and urinary system malformations $(0.3 \%)$. Birth defect incidence in PGWV children conceived after the mission was similar to birth defect incidence described by the Paris Registry of Congenital Malformations, except for Down syndrome (PGWV children incidence was lower than Registry incidence).

Conclusion: This study did not highlight a high frequency of fertility disorders or miscarriage among French PGW veterans. We found no evidence for a link between paternal exposure during the Gulf War and increased risk of birth defects among French PGWV children.
\end{abstract}




\section{Background}

In late 1990 and early 1991, approximately 20,000 French troops were deployed in the First Gulf War. Since 1993, many studies on the health of Persian Gulf War veterans (PGWVs) have been undertaken, mainly in the USA and the UK. US and UK mortality studies have shown a lower mortality from all illnesses among Gulf War veterans in comparison to non-deployed veterans and an increased mortality from external causes consistent with patterns of postwar mortality observed in veterans of previous wars [1-4]. Compared to non-deployed veterans, PGWVs have been reported to have no excess of recognized diseases [517] but were 2-3 times more likely to report fatigue, cognitive difficulties, headaches, myalgia and arthralgia, mood disturbances, and sleep problems [5-17].

Several studies have been conducted on reproductive outcomes [18-31], mainly focused on pregnancy outcomes and birth defects $[18-25,27,29-31]$, but no specific studies on spermatogenesis anomalies.

One study did not find any difference between the reproductive hormones measured in Gulf War veterans and in controls [24]. However, compared with non-deployed controls, Gulf War veterans had a significantly higher risk of reported infertility (OR: 1.4 to 1.5 according to the fertility type) [28] and a higher risk of self-reported sexual problems (OR: $3.5-\mathrm{p}<0,001$ ) [24].

Pregnancies fathered by Gulf War veterans took longer to conceive [28]. Conceptions of exposed and nondeployed veterans have similar outcomes $[20,23,26]$, and no differences in pre-term deliveries are described $[25,29,30]$. Female Gulf War veterans had a higher risk of ectopic pregnancies than non-deployed veterans [20]. The increase of miscarriage or spontaneous abortion was not consistent between the different studies [20,22-26]. Compared with non-deployed veterans, Gulf War veterans reported the same risk of stillbirth $[23,25,26]$ or infant mortality [25].

Most of the studies on the children of Gulf War veterans found no evidence of an increase in the risk of birth defects $[18,21,22,24,29,31]$ or congenital diseases $[22,24]$. Some authors reported a higher prevalence of reported birth defects in babies of Gulf War veterans conceived after the Gulf War $[22,23,25]$. When looking at specific defects, only Araneta et al [19] observed a higher prevalence of renal agenesis and hypoplasia among children conceived postwar to GWV men, adjusted for prenatal alcohol exposure and intrauterine growth retardation. The other birth defects described (cardiac valve disorder among children conceived postwar to GWV men and hypospadias among children conceived postwar to GWV women) were no longer significant after adjustment for maternal parameters, branch of military service, and military rank [19].

For Doyle et al [32], there is no strong or consistent evidence in the literature of an effect of paternal service in the first Gulf War on the risk of major birth defects or stillbirth in offspring conceived after deployment, even if effects on specific rare defects cannot be excluded. There is some evidence of small increased risks of miscarriage or infertility associated with service, but the role of bias cannot be ruled out [32]. Finally, with regards to female veterans, firm conclusions cannot be drawn due to lack of sufficient information [32].

The present study reports findings relating to the reproductive outcome and health of offspring of French Gulf War veterans. The French Study on the Persian Gulf War and its Health Consequences is an exhaustive investigation into all French PGWVs conducted from 2002 to 2004. The aim of this descriptive study was, mainly, to examine self-reported symptom data among Gulf War veterans and to describe the main exposures reported in the theater, the symptoms and diseases that appeared during and after the Persian Gulf mission, and children's health.

\section{Methods \\ Population study}

Detailed information about this study is given elsewhere [33]. In brief, the French Study on the Persian Gulf War and its Health Consequences is a cross-sectional study with an exhaustive aim which included all civilians and military personnel serving in the Persian Gulf from August 1990 to July 1991 . The addresses of 10,478 French troops who served in the Gulf during the period from August 1990 through July 1991 were identified, based on data transmitted by military staff, and 5,666 participated in the study after receiving two reminders. The participation rate was $54 \%$ and varied by branch of service $56 \%$ in the Army, 55\% in the Air Force, and 43\% in the Navy).

\section{Questionnaire}

Data collection was based on a 12-page self-administered postal questionnaire, accompanied by an explanatory letter stating the objectives of our study and a consent form, was developed on the basis of information published in the French authorities' reports and with reference to questionnaires used in PGWV morbidity studies. The questionnaire, tested on a sample of the target population, requested details of disorders requiring medical consultation, miscarriage or stillbirth, and the number of children born before and after the conflict. If a child presented a disease, his or her year of birth, gender, and detailed illnesses were requested. The notion of infertility was inferred from the following specific disorders: infertility or sperm abnormalities. The questionnaire also explored 
(i) socio-demographic characteristics (gender, age), (ii) military history (service branch, rank, military status on completion of the questionnaire), (iii) living conditions, and self-reported exposures during the Persian Gulf mission (sandstorms, smoke from oil well fires, chemical or bacteriological alerts, vaccinations, medication, and pesticides) of the PGWVs, and (iv) diseases and symptoms before, during, and after the mission. Hospitalization after the mission for one of the 49 symptoms of the Hopkins Symptom Checklist [34] was also reported.

On reception, the questionnaires were made anonymous, coded by an epidemiologist (CV) [ICD-10 [35]], keyboarded, and analyzed. Birth defects presented by PGWV offspring were grouped for analysis based on the classification system used in the European Registry of Congenital Anomalies (EUROCAT) [36].

\section{Statistical analysis}

We used Stata ${ }^{\mathrm{TM}}$ statistical software for all analyses. All p values are two sided, and we took values less than 0.05 to indicate statistical significance.

First, a descriptive analysis was conducted on PGWV: i) living conditions and exposures during the mission; ii) self-reported infertility disorders and miscarriage that appeared after the PGW mission.

Secondly, as data on healthy children were not available (except for the number of children), we decided to perform a case-control study nested within the cohort to determine the effect of PGW exposures on the risk of a father conceiving a child with a birth defect after the war. The date of birth had to be later than nine months after the end of the PGW mission for a child to be considered as having been conceived after the war. A case was defined as a man having had at least one child conceived after the PGW mission and presenting at least one birth defect. Two controls were selected for each case. A control was defined as a man of the same age as the case ( \pm 1 year) who had never had a child with a birth defect but who had had at least one child after the PGW mission. Fathers having had at least one child with a birth defect before the PGW were excluded from this analysis. To minimize recall bias, a control should have reported one hospitalization for at least one symptom of the Hopkins Symptom Checklist [34] after the mission. PGW exposure odds-ratios were estimated by conditional logistic regression and then adjusted for service branch, rank, and military status.

Finally, the study provides a description of children born to PGWVs after the Gulf War. Major anomalies were described as Maconochie et al reported [27]. Minor anomalies were coded and specified. As no national registry on birth defects has been developed in France, PGWV chil- dren's birth defect rates were compared to the 10-year incidence rate of birth defects among children conceived from 1991 to 2000, as described by the Paris Registry of Congenital Malformations [37]. The Paris Registry rate was considered as the reference rate among the population. The confidence interval of the PGWV children's birth defect rate was estimated according to a Poisson distribution. The incidence ratio was calculated by dividing the PGWV children's birth defect rate by the reference rate.

The National Commission of Data Processing and Civil Liberty approved this investigation, in conformity with article 15, paragraph 3 of the Law of January 6, 1978, concerning data processing, files, and civil liberty.

\section{Results \\ Study population}

Most of the 5,666 subjects who completed the questionnaire were male $(99.5 \%)$, with an average age of 41 years (SD: 6 years) at the time of completion of the survey, and $71 \%$ of respondents were still in service. Considering the sample size of female veterans, the results are presented below by gender.

\section{Reproductive health of French female Persian Gulf War veterans}

The mean age of the 28 women who completed the questionnaire was 44 years ( 37 to 57 years). They served mainly in military health services $(\mathrm{n}=14)$ and in the Air Force $(n=12)$. One woman served in the Navy and one in the Army. Six women reported at least one miscarriage after the mission. Nine women reported having at least one child after the mission (total of 25 babies), ranging from 1 to 4 children. No birth defect was reported in children born after the mission.

\section{Reproductive health of French male Persian Gulf War veterans}

The main characteristics of the 5,638 male veterans are presented in Table 1. Respondents served mainly in the Army or the Air Force and were servicemen. The respondents' age varied according to service: $63 \%$ of Army veterans, $52 \%$ of Navy veterans, and $28 \%$ of Air Force veterans were less than 40 years old $(\mathrm{p}<0,001)$.

\section{Infertility and other reproductive outcomes}

Infertility and reproductive outcomes are described in 5,638 male veterans. Infertility problems (such as spermogram anomalies) were reported by 48 respondents, mainly Army veterans (Table 1).

After deployment, 3,121 veterans fathered at least one child (corresponding to 5,158 babies). The number of pregnancies reported per father varied from 1 to 10 pregnancies. 
Table I: Main Characteristics and Reproductive History of French Male Persian Gulf War Veterans $(\mathbf{N}=\mathbf{5 , 6 3 8})$

\begin{tabular}{|c|c|c|c|c|c|c|c|c|c|c|}
\hline & \multicolumn{2}{|c|}{ Army $(n=2,694)$} & \multicolumn{2}{|c|}{ Navy $(n=769)$} & \multicolumn{2}{|c|}{ Air Force $(n=1,883)$} & \multicolumn{2}{|c|}{ Other branch* $(n=292)$} & \multicolumn{2}{|c|}{ Total $(n=5,638)$} \\
\hline & $\mathrm{n}$ & $\%$ & $\mathrm{n}$ & $\%$ & $\mathrm{n}$ & $\%$ & $\mathrm{n}$ & $\%$ & $\mathrm{n}$ & $\%$ \\
\hline \multicolumn{11}{|l|}{ Main characteristics } \\
\hline \multicolumn{11}{|l|}{ Rank } \\
\hline Officers & 277 & 10.3 & 101 & 13.1 & 364 & 19.3 & 120 & 41.1 & 862 & 15.3 \\
\hline Non-commissioned officers & 962 & 35.7 & 435 & 56.6 & 1,431 & 76.0 & 122 & 41.8 & 2,950 & 52.3 \\
\hline Servicemen & 1,455 & 54.0 & 233 & 30.3 & 88 & 4.7 & 50 & 17.1 & 1,826 & 32.4 \\
\hline \multicolumn{11}{|l|}{ Age (at the beginning of the study) } \\
\hline$<40$ years & 1,699 & 63.1 & 401 & 52.1 & 528 & 28.0 & 68 & 23.3 & 2,696 & 47.8 \\
\hline$>=40$ years & 995 & 36.9 & 368 & 47.9 & 1,355 & 72.0 & 224 & 76.7 & 2,942 & 52.2 \\
\hline \multicolumn{11}{|l|}{ Military status } \\
\hline Active & 1,980 & 73.5 & 668 & 86.9 & 1,202 & 63.8 & 190 & 65.1 & 4,040 & 71.7 \\
\hline Retired & 714 & 26.5 & 101 & 13.1 & 681 & 36.2 & 102 & 34.9 & 1,598 & 28.3 \\
\hline \multicolumn{11}{|c|}{ Reproductive history after the PGW mission } \\
\hline Fathers having at least one child (live birth) & $\mathrm{I}, 706$ & 63.3 & 436 & 56.7 & 853 & 45.3 & 126 & 43.2 & 3,121 & 55.4 \\
\hline at least one conceived before and after GW & 406 & 15.1 & 132 & 17.2 & 354 & 18.8 & 63 & 21.6 & 955 & 16.9 \\
\hline \multicolumn{11}{|c|}{ Number of live births per father (after the mission) } \\
\hline 0 & 988 & 36.7 & 333 & 43.3 & 1,030 & 54.7 & 166 & 56.8 & 2,517 & 44.6 \\
\hline 1 & 719 & 26.7 & 190 & 24.7 & 382 & 20.3 & 61 & 20.9 & 1,352 & 24.0 \\
\hline 2 & 710 & 26.4 & 175 & 22.8 & 344 & 18.3 & 40 & 13.7 & 1,269 & 22.5 \\
\hline$>=3$ & 227 & 8.4 & 55 & 7.2 & 91 & 4.8 & 20 & 6.8 & 393 & 7.0 \\
\hline Any miscarriage or stillbirth & 395 & 14.7 & 96 & 12.5 & 170 & 9.0 & 21 & 7.2 & 682 & 12.1 \\
\hline at least one before and after GW & 16 & 0.6 & 5 & 0.7 & 9 & 0.5 & 3 & 1.0 & 33 & 0.6 \\
\hline Infertility reported & 35 & 1.3 & 5 & 0.7 & 6 & 0.3 & 2 & 0.7 & 48 & 0.9 \\
\hline Father with child born with birth defects & 69 & 2.6 & 15 & 2.0 & 45 & 2.4 & 6 & 2.1 & 135 & 2.4 \\
\hline at least one before and after GW & 0 & 0.0 & 2 & 0.3 & 2 & 0.1 & 0 & 0.0 & 4 & 0.1 \\
\hline
\end{tabular}

* Other branch of service: state public force, medical military service

After deployment, 682 male veterans (12\%) reported at least one miscarriage by their partner, 33 of whom reported a miscarriage before and after the mission. Overall, 135 men ( $4.3 \%$ of fathers) reported at least one child born with at least one birth defect (140 children), of which 4 reported having one child presenting a birth defect both before and after the mission ( 8 children). After the PGW mission, 131 fathers (4.2\%) reported at least one child born with a birth defect, without having conceived a child with a birth defect before the PGW mission.

Case-control study of PGW-related exposures on any birth defects The case-control study of PGW-related exposures on any birth defects included 131 cases and 262 controls. The 262 controls were randomized among the 845 veterans who had reported one hospitalization for at least one symptom (14.9\% of participants), and matched for age (+/- one year). Characteristics of subjects in terms of branch of service, rank and military status, and crude and adjusted odds ratios for any birth defects are presented in Table 2 .

Cases did not differ from controls according to service branch, rank, or military status.
Description of PGW-related exposures and odds ratios for any birth defects adjusted for branch of service, rank, and military status are presented in Table 3.

Service period and locations for the PGW mission (Iraq and/or Kuwait) were not different for cases and controls. Concerning PGW-related exposures, cases reported an identical exposure to the smoke of oil well fires, sandstorms, chemical alarms, and pesticides. Controls more often reported an exposure to sounding of chemical alarms (74.8\% vs 64.9\%), which did not persist after adjustment for service branch, rank, and military status.

\section{Health of live born children}

The health of live born children and birth defects are described in 5,183 children conceived after the PGW mission. Incidence of pre-term delivery reported in children conceived after the PGW mission was 104.2/10,000 live births [95\% CI: 78.3-135.9]. Only 140 babies conceived after the PGW mission presented at least one birth defect (270.1/10,000 live births [95\% CI: 227.2-318.7]). Eight babies presented two malformations. These associations were not specific.

The different major birth defects of babies conceived after the Gulf War mission are presented in Table 4. 
Table 2: Crude and Adjusted Odds Ratios for Any Birth Defect - Role of Service, Rank, Military Status

\begin{tabular}{|c|c|c|c|c|c|c|c|c|c|c|}
\hline & \multicolumn{2}{|c|}{ Cases $(n=|3|)$} & \multicolumn{2}{|c|}{ Controls $(n=262)$} & \multicolumn{3}{|c|}{ Univariate analysis } & \multicolumn{3}{|c|}{ Adjusted analysis * } \\
\hline & $\mathrm{n}$ & $\%$ & $\mathrm{n}$ & $\%$ & OR & $95 \% \mathrm{Cl}$ & $P$ & OR & $95 \% \mathrm{Cl}$ & $P$ \\
\hline Age in 1990 & & & & & 1.02 & $0.83-1.25$ & 0.84 & 1.02 & $0.83-1.27$ & 0.81 \\
\hline Service & & & & & & & 0.06 & & & 0.08 \\
\hline Navy & 13 & 9.9 & 24 & 9.2 & 1.00 & & & 1.00 & & \\
\hline Army & 69 & 52.7 & 169 & 64.5 & 0.75 & $0.35-1.62$ & & 0.74 & $0.33-1.61$ & \\
\hline Air Force & 43 & 32.8 & 58 & 22.1 & 1.69 & $0.70-4.07$ & & 1.72 & $0.71-4.17$ & \\
\hline Other branch & 6 & 4.6 & 11 & 4.2 & 1.23 & $0.31-4.9 \mid$ & & 1.16 & $0.28-4.77$ & \\
\hline Rank & & & & & & & 0.60 & & & 0.60 \\
\hline Officers & 15 & 11.5 & 24 & 9.2 & 1.00 & & & 1.00 & & \\
\hline Non-commissioned officers & 58 & 44.3 & 114 & 43.5 & 0.77 & $0.36-1.65$ & & 0.69 & $0.31-1.56$ & \\
\hline Servicemen & 58 & 44.3 & 124 & 47.3 & 0.64 & $0.27-1.54$ & & 0.86 & $0.33-2.21$ & \\
\hline \multicolumn{11}{|l|}{ Military status } \\
\hline Active & 99 & 75.6 & 191 & 72.9 & 1.00 & & & 1.00 & & \\
\hline Retired & 32 & 24.4 & 71 & 27.1 & 0.87 & $0.53-1.4 \mid$ & 0.57 & 0.82 & $0.49-1.36$ & 0.44 \\
\hline
\end{tabular}

* adjusted odds ratio for service branch, rank, and military status

The main birth defects reported in babies conceived after the mission were anomalies of the musculoskeletal system (rate: 46.3/10,000) and urinary system anomalies $(34.7 / 10,000)$. However, no specific birth defect was found. Only 21 children conceived in the first two years following the conflict presented birth defects, mainly malformations of the digestive system.

\section{Comparison with the Paris Registry of Congenital Malformations}

The birth defect frequencies estimated after deployment were compared to available French data (Paris Registry of Congenital Malformations, 1991-2000). The 10-year birth defect incidence rate of children conceived after deployment $(270.1 / 10,000$ [227.2-318.7]) was not dif-

Table 3: Crude and Adjusted Odds Ratios for Any Birth Defect - Role of PGW-Related Exposures

\begin{tabular}{|c|c|c|c|c|c|c|c|c|c|c|}
\hline & \multicolumn{2}{|c|}{ Cases $(n=|3|)$} & \multicolumn{2}{|c|}{ Controls $(n=262)$} & \multicolumn{3}{|c|}{ Univariate analysis } & \multicolumn{3}{|c|}{ Adjusted analysis * } \\
\hline & $\mathrm{n}$ & $\%$ & $\mathrm{n}$ & $\%$ & OR & $95 \% \mathrm{Cl}$ & $\mathrm{P}$ & OR & $95 \% \mathrm{Cl}$ & $\mathrm{P}$ \\
\hline Mission in GW & & & & & & & 0.17 & & & 0.31 \\
\hline Before Jan. 1991 & 12 & 9.2 & 35 & 13.4 & 1.00 & & & 1.00 & & \\
\hline After Feb. 1991 & 6 & 4.6 & 20 & 7.6 & 0.85 & $0.28-2.58$ & & 0.85 & $0.27-2.66$ & \\
\hline Only Jan-Feb. I991 & 17 & 13.0 & 19 & 7.3 & 2.33 & $0.97-5.59$ & & 1.88 & $0.75-4.75$ & \\
\hline Other date of mission & 96 & 73.3 & 188 & 71.7 & 1.43 & $0.70-2.91$ & & 1.61 & $0.76-3.40$ & \\
\hline Location of mission & & & & & & & 0.47 & & & 0.90 \\
\hline Neither Iraq nor Kuwait & 72 & 55.0 & 122 & 46.6 & 1.00 & & & 1.00 & & \\
\hline Kuwait only & 10 & 7.6 & 23 & 8.8 & 0.73 & $0.32-1.66$ & & 0.74 & $0.30-1.78$ & \\
\hline Iraq only & 41 & 31.3 & 96 & 36.6 & 0.72 & $0.44-1.17$ & & 0.97 & $0.53-1.78$ & \\
\hline Iraq and Kuwait & 8 & 6.1 & 21 & 8.0 & 0.66 & $0.28-1.58$ & & 0.84 & $0.33-2.10$ & \\
\hline \multicolumn{11}{|l|}{ Smoke of oil well fires } \\
\hline No & 90 & 68.7 & 176 & 67.2 & 1.00 & & & 1.00 & & \\
\hline Yes & 41 & 31.3 & 86 & 32.8 & 0.93 & $0.59-1.47$ & 0.76 & 0.90 & $0.56-1.43$ & 0.65 \\
\hline \multicolumn{11}{|l|}{ Sandstorm } \\
\hline No & 25 & 19.1 & 49 & 18.7 & 1.00 & & & 1.00 & & \\
\hline Yes & 106 & 80.9 & 213 & 81.3 & 0.98 & $0.58-1.65$ & 0.93 & 1.15 & $0.57-2.31$ & 0.69 \\
\hline \multicolumn{11}{|l|}{ Chemical alarms } \\
\hline No & 46 & 32.1 & 66 & 25.2 & 1.00 & & & 1.00 & & \\
\hline Yes & 85 & 64.9 & 196 & 74.8 & 0.63 & $0.40-0.99$ & 0.05 & 0.61 & $0.36-1.06$ & 0.08 \\
\hline \multicolumn{11}{|l|}{ Pesticides } \\
\hline No & 86 & 65.7 & 178 & 67.9 & 1.00 & & & 1.00 & & \\
\hline Yes & 45 & 34.4 & 84 & 32.1 & 1.11 & $0.70-1.78$ & 0.64 & 1.00 & $0.6 \mathrm{I}-1.63$ & 0.99 \\
\hline
\end{tabular}

* adjusted odds ratio for age, service branch, rank, and military status 
Table 4: Major Birth Defects* among French PGWV's Children Born after the Mission $(\mathbf{N}=5,183)$

\begin{tabular}{|c|c|c|c|c|c|}
\hline & \multicolumn{2}{|c|}{ Children born in } & \multicolumn{3}{|c|}{ All children } \\
\hline & $1991-1992$ & $1993-200 \mid$ & Total & Rate (p.10,000) & {$[95 \% \mathrm{Cl}]$} \\
\hline Any major birth defect & 21 & 119 & 140 & 270.1 & [227.2-318.7] \\
\hline Central nervous system & 2 & 4 & 6 & 11.6 & {$[4.2-25.2]$} \\
\hline Neural tube defects & I & 2 & 3 & 5.8 & {$[1.2-16.9]$} \\
\hline Hydrocephalus & 0 & I & 1 & 1.9 & {$[0.1-10.8]$} \\
\hline Other malformation of central nervous system & I & I & 2 & 3.9 & {$[0.5-13.9]$} \\
\hline Eye, ear, face and neck & I & 8 & 9 & 17.4 & {$[7.9-33.0]$} \\
\hline Eye & I & 3 & 4 & 7.7 & {$[2.1-19.8]$} \\
\hline Ear & 0 & 2 & 2 & 3.9 & {$[0.5-13.9]$} \\
\hline Other malformation of eye, ear, face, nose & 0 & 3 & 3 & 5.8 & {$[1.2-16.9]$} \\
\hline Circulatory system & 2 & 13 & 15 & 28.9 & {$[16.2-47.7]$} \\
\hline Congenital malformation of heart & 0 & 12 & 12 & 23.2 & {$[12.0-40.4]$} \\
\hline Other malformation of circulatory system & 2 & I & 3 & 5.8 & {$[1.2-16.9]$} \\
\hline Respiratory system & I & 2 & 3 & 5.8 & {$[1.2-16.9]$} \\
\hline Cleft lip/palate & 0 & 3 & 3 & 5.8 & {$[1.2-16.9]$} \\
\hline Digestive system & 3 & 10 & 13 & 25.1 & [13.4-42.9] \\
\hline TOF and other malformations of large intest., rectum, anal canal & 0 & 3 & 3 & 5.8 & {$[1.2-16.9]$} \\
\hline Other malformation of digestive system & 3 & 7 & 10 & 19.3 & {$[9.3-35.5]$} \\
\hline Genital system & 2 & 8 & 10 & 19.3 & {$[9.3-35.5]$} \\
\hline Urinary system & 2 & 16 & 18 & 34.7 & [20.6-54.9] \\
\hline Renal anomalies & 0 & 7 & 7 & 13.5 & {$[5.4-27.8]$} \\
\hline Urinary tract anomalies & 2 & 9 & 11 & 21.2 & {$[10.6-38.0]$} \\
\hline Musculoskeletal system & 4 & 20 & 24 & 46.3 & [29.7-68.9] \\
\hline Limb reduction & 0 & 2 & 2 & 3.9 & {$[0.5-13.9]$} \\
\hline Polydactyly and syndactyly & 0 & 3 & 3 & 5.8 & {$[1.2-16.9]$} \\
\hline Other limb malformation & I & 11 & 12 & 23.2 & {$[12.0-40.4]$} \\
\hline Anomalies of diaphragm, exomphalus, gastrochisis & 0 & 3 & 3 & 5.8 & {$[1.2-16.9]$} \\
\hline Other musculoskeletal anomalies & 3 & 3 & 6 & 11.6 & {$[4.2-25.2]$} \\
\hline Other specific non-chromosomal syndromes & 2 & 7 & 9 & 17.4 & {$[7.9-33.0]$} \\
\hline Specified syndromes (non-chromosomal) & 0 & 3 & 3 & 5.8 & {$[1.2-16.9]$} \\
\hline Other non-chromosomal malformations & 2 & 4 & 6 & 11.6 & {$[4.2-25.2]$} \\
\hline Chromosomal & 2 & 12 & 14 & 27 & {$[14.8-45.3]$} \\
\hline Down syndrome & 2 & 4 & 6 & 11.6 & {$[4.2-25.2]$} \\
\hline Other chromosomal & 0 & 8 & 8 & 15.4 & {$[6.7-30.4]$} \\
\hline
\end{tabular}

\footnotetext{
* excluded: minor or unspecified anomalies of ear, undescended testes, unspecified congenital deformity of hip, unspecified congenital deformity of feet,
} naevus

ferent from the incidence of the birth defect Registry (261.0/10,000 [255.8-266.2]; ratio: 1.03 [95\%CI: 0.91.2]). Figure 1 presents the incidence ratios of the main birth defects and their 95\% confidence intervals.

Compared with the Registry birth defect incidence, no main birth defect was higher in the veterans' children group. Only Down syndrome incidence was statistically lower in the veterans' children group than in the Registry one (rate of veterans' children group: 11.6/10,000 [95\% CI: 4.2-25.2] - Registry: 32.2/10,000 [30.4-34.1]; incidence ratio: 0.4 [95\%CI: $0.1-0.8]$ ]).

\section{Discussion}

In this study, $1 \%$ of the Gulf veterans reported fertility disorders and $12 \%$ of male veterans reported at least one miscarriage among their partners after the PGW mission. Overall, $4.2 \%$ of fathers reported at least one child born 


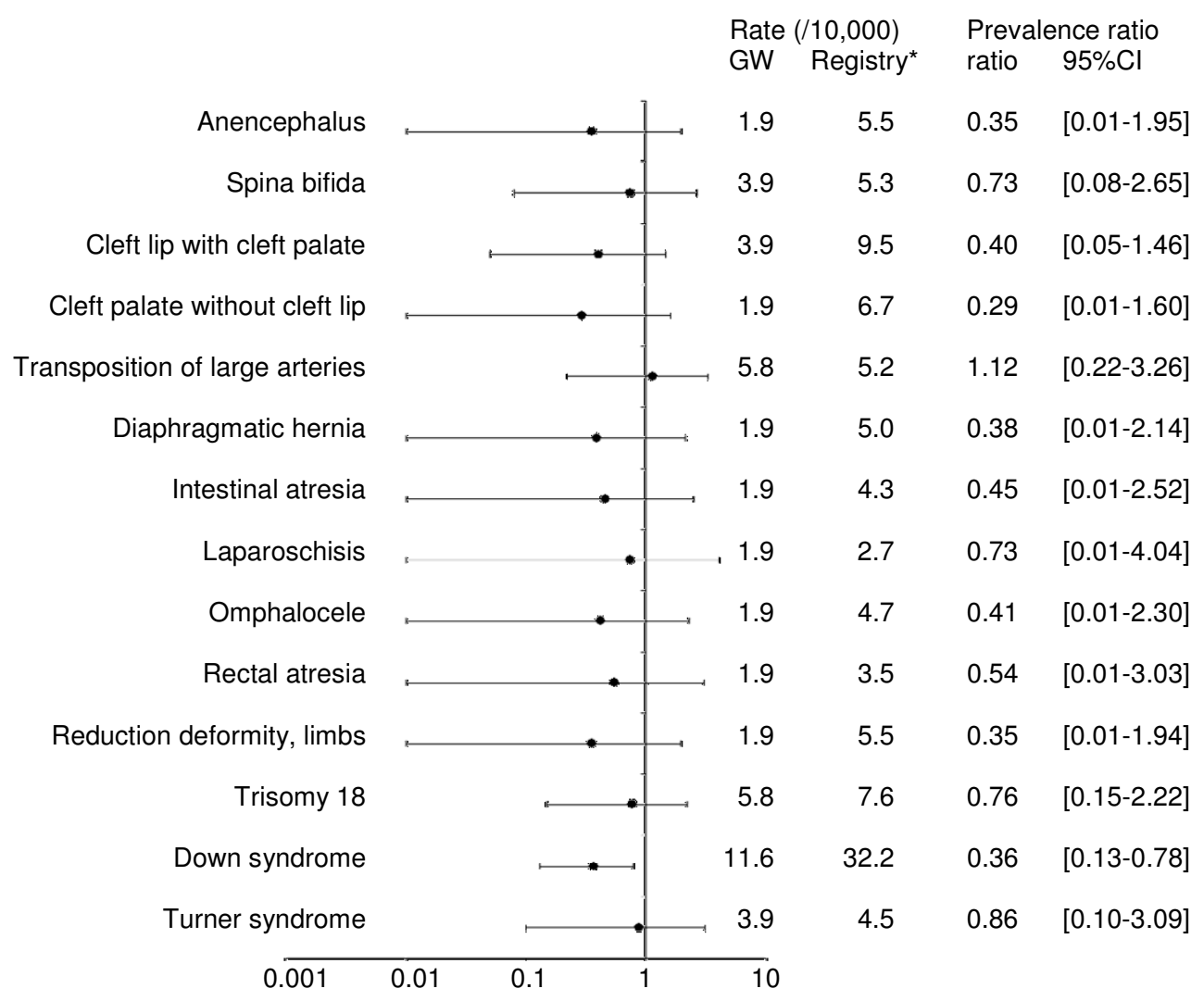

\section{Figure I}

Rates of Congenital Malformations in PGWV' children and in the Paris Registry of Congenital Malformations. * I0-year incidence

with a birth defect after the mission. No PGW-related exposure was associated with any birth defect in children fathered after the PGW mission. Concerning the reported health of children born after the PGW mission, $1.0 \%$ of children were born with pre-term delivery and $2.7 \%$ presented a birth defect. The main birth defects reported were musculoskeletal malformations $(0.5 \%)$ and urinary system malformations $(0.3 \%)$. Birth defect incidence in PGWV children conceived after the mission was similar to birth defect incidence described by the Paris Registry; except for Down syndrome, where the incidence in PGWV children was lower than the Paris Registry incidence.

Results are reported with several reservations. Although we sent out two reminders, our study did not have a high response rate, which suggests selective participation by respondents according to health outcome. The French Study on the Persian Gulf War and its Health Consequences aimed to be exhaustive, offering a free medical examination to all veterans provided by the French Government. The media in foreign countries gave massive coverage to complaints lodged due to the health conse- quences of the Gulf War, so respondents with health disorders, or at least worried about them, were more willing to participate in our study. However, this bias could be partly compensated for by the fact that $71 \%$ of respondents were still in service.

Data were gathered retrospectively and were based on veterans' self-reported data and were not validated against medical records for healthy veterans or their children. However, it is probable that symptoms or serious diseases requiring specific care or of unusual frequency or intensity were reported more often than events considered as slight or benign.

Recall bias can be a serious problem in case-control studies; when pre-recorded written exposure information is unavailable, controls with identical stimuli should be selected (e. g. a control series of children with malformations other than the one under study) [38]. We conducted a case-control study including controls matched for age and who reported one hospitalization for at least one symptom in order to minimize the recall bias. 
A direct relationship of birth defects to characteristics of the PGW mission could not be shown because i) data were collected retrospectively on a 10 -year period, ii) information was based on the declarations of the PGW veterans (most were men, with no information on the children's mother), and iii) this study can only highlight associations between exposures and diseases and not evidence. Moreover, many children were conceived long after the war itself, personal risk factors (i.e., family history or history of another child with a birth defect) were not examined, and there is a potential for misreporting. No information was available on the use of medication. Results must be interpreted with caution due to the small number of case children for specific birth defects. Despite these major limitations, frequencies shown in French PGWVs were similar to frequencies in the French general population, except for the low frequency of Down syndrome. In our study, dates of birth of the unaffected children were not available and fathers' ages at birth were not known. However, $82 \%$ of fathers were 25 to 35 years old during the period covered by the study. Paternal age is related to maternal age and the risk of infecundity, miscarriage, and birth defects seems to increase with paternal age $[39,40]$. In the registry, $22 \%$ of mothers were above 35 years of age [37]. The analysis could not be controlled for mothers' age or parity.

The results of fertility studies on Gulf War veterans are controversial. The first studies published $[24,28]$ did not find any effect of Gulf War service on markers of male fertility (hormone measurements, oligospermia, azoospermia, asthenospermia, teratospermia, sexual problems). However, some authors described an increased risk of infertility reaching $7 \%$ to $14 \%[25,26]$, mainly due to an increase of teratospermia and oligoasthenospermia [28]. The low estimation $(0.9 \%)$ in our study could be explained by the self-reported infertility data collected in this study. Besides these sperm anomalies, pregnancies fathered by PGWVs seemed to take longer to conceive [27].

Authors reported an increased risk of miscarriage among partners of PGWVs, compared to a control group $[22,23,25-27]$, ranging from $12 \%$ to $60 \%$ among first pregnancies conceived after the PGW mission [25]. In our study, this miscarriage rate was $12 \%$ after the mission.

Concerning children's health in our study, the frequency of pre-term delivery $(1.0 \%)$ was lower than frequencies described in other studies on PGW veterans (ranging from $0.6 \%$ to $10.9 \%)[18,19,23,25,26,30]$.

In our study, the frequency of birth defects was slightly lower $(2.7 \%)$ than the frequencies described in other studies (ranging from 3.6 to $9.0 \%$ ) $[21-23,25,26]$. The rate of birth defects among the French general population is estimated at 3.2\% of all births for the period 1981-2000 [37]. No specific birth defect was highlighted in our study. Moreover, as one hypothesis was that wartime exposures adversely affected spermatogenesis, it was therefore reasonable to evaluate conceptions that occurred 70-90 days after leaving the war environment. The assessment of conceptions that occurred 3-10 years after the PGW mission would be more a reflection of non-war exposures and advanced paternal age than of distant wartime exposures. Since the number of live births per year was not available, in order to show a statistical difference between the birth defect rates of each of the two periods (1991-1992 vs 1993-2001), we estimated by simulation that fewer than 700 live births were needed in 1991-1992 (i.e. 13\% of all children born after the PGW mission). However, this figure did not seem plausible in view of the context (a return home after an overseas mission). Specific birth defect frequencies were lower in our study than frequencies described by Doyle [22] in UK PGWVs: malformations of the musculoskeletal system $(8.0 \%$ in Doyle's study $v$ s $4.6 \%$ in our study), or malformations of the urinary system (4.9\%o in Doyle's study vs 3.5\%o in our study). The frequency of renal anomalies (1.4\%o) was similar to that described by Araneta [19] in US PGWVs (1.1\%o), and chromosomal anomalies were similar to those previously described $(2.7 \%$ in our study, $0.2 \%$ o to $2.6 \%$ in the literature) $[19,25]$. Since 1970 , the increase in malformations of the urinary, central nervous, and cardiac systems could be explained by the widespread use of ultrasound, (particularly in antenatal diagnosis), which can identify malformations even without clinical symptomatology.

A combination of genetic and environmental factors may be responsible for 20 to $25 \%$ of congenital anomalies [41]. US Gulf veterans were exposed to many chemical, biological, and physical agents suspected of being reproductive toxins [42]. Constant infertility over time of UK veterans, described by Maconochie [28], argues in favor of either paternal germ cell mutation or other damage to spermatogenic stem cells necessary for supporting spermatogenesis. Combined exposure to pyridostigmine bromide, the insect repellent DEET, and the insecticide permethrin seemed to induce apoptosis in rat testicular germ cells, Sertoli cells, and Leydig cells [43]. However, Arfsten [44] showed that implantation of depleted uranium in adult rats does not have an adverse impact on male reproductive success, sperm concentration, or sperm velocity. Our case-control analysis did not highlight the role of PGW-related exposures in birth defects among PGWV children.

\section{Conclusion}

In conclusion, this study found the same frequencies of fertility disorders, miscarriage, and health disorders 
among PGWV children as those described among foreign PGWVs and the French general population. No PGWrelated exposure was associated with any birth defect in children fathered after the PGW mission. Our findings are limited by the reliability of self-reported data concerning exposures and health and pregnancy outcomes. This study highlights the importance of prospective data collection for exposures during future foreign operations and epidemiological surveillance of servicemen and women.

However, if the fertility disorders and birth defects remain constant over time, a more detailed and focused survey would be required to examine fertility and other aspects of reproduction more thoroughly.

\section{Competing interests}

The French Study on Persian Gulf War and its Health Consequences was funded by the French Ministry of Defense.

\section{Authors' contributions}

CV carried out study design, statistical analyses and drafting the manuscript, MAJ supervised all aspects of study design and statistical analyses, CDV helped to findings interpretation on birth defects analyses, MB participated in study design and carried out data collection, LBC helped revise the manuscript, PB supervised analyses and helped revise the manuscript, RS was the principal investigator and supervised all aspects of study implementation. All authors read and approved the final manuscript.

\section{Acknowledgements}

We gratefully acknowledge the contributions of Véronique Bigorie, Brigitte Manoux, Evelyne Mouillet, Eric Pin, and thank Dr. André Spiegel for his advice on this manuscript. Lastly, but most importantly, we sincerely thank the French Gulf War Veterans for their participation.

\section{References}

I. Gray GC, Gackstetter GD, Kang HK, Graham JT, Scott KC: After more than 10 years of Gulf War veteran medical evaluations, what have we learned? Am J Prev Med 2004, 26(5):443-452.

2. Kang HK, Bullman TA: Mortality among U.S. veterans of the Persian Gulf War. N Engl J Med 1996, 335(20): I 498-I504.

3. Kang HK, Bullman TA, Macfarlane GJ, Gray GC: Mortality among US and UK veterans of the Persian Gulf War: a review. Occup Environ Med 2002, 59( I 2):794-799.

4. Macfarlane GJ, Thomas E, Cherry N: Mortality among UK Gulf War veterans. Lancet 2000, 356(9223): I7-2I.

5. Unexplained illness among Persian Gulf $W$ ar veterans in an Air National Guard Unit: preliminary report - August 1990March 1995. MMWR Morb Mortal Wkly Rep 1995, 44(23):443-447.

6. Self-reported illness and health status among Gulf War veterans. A population-based study. The lowa Persian Gulf Study Group. Jama 1997, 277(3):238-245.

7. Amato AA, McVey A, Cha C, Matthews EC, Jackson CE, Kleingunther R, Worley L, Cornman E, Kagan-Hallet K: Evaluation of neuromuscular symptoms in veterans of the Persian Gulf War. Neurology 1997, 48(I4-12 [http://www.neurology.org/cgi/content/full/ 48/I/4].

8. Barrett DH, Gray GC, Doebbeling BN, Clauw DJ, Reeves WC: Prevalence of symptoms and symptom-based conditions among Gulf War veterans: current status of research findings. Epidemiol Rev 2002, 24(2):218-227.
9. Coker WJ, Bhatt BM, Blatchley NF, Graham JT: Clinical findings for the first 1000 Gulf war veterans in the Ministry of Defence's medical assessment programme. Bmj 1999, 3 | 8(7 I 79):290-294.

10. Engel CC Jr, Ursano R, Magruder C, Tartaglione R, Jing Z, Labbate LA, Debakey S: Psychological conditions diagnosed among veterans seeking Department of Defense Care for Gulf Warrelated health concerns. J Occup Environ Med 1999, 4I(5):384-392.

II. Gray GC, Kaiser KS, Hawksworth AW, Hall FW, Barrett-Connor E: Increased postwar symptoms and psychological morbidity among U.S. Navy Gulf War veterans. Am J Trop Med Hyg 1999, 60(5):758-766.

12. Gray GC, Reed RJ, Kaiser KS, Smith TC, Gastanaga VM: Selfreported symptoms and medical conditions among II,868 Gulf War-era veterans: the Seabee Health Study. Am J Epidemiol 2002, I 55( I I ): 1033-1044.

13. Kang HK, Mahan CM, Lee KY, Magee CA, Murphy FM: Illnesses among United States veterans of the Gulf War: a population-based survey of 30,000 veterans. J Occup Environ Med 2000, 42(5):49I-50।.

14. Proctor SP, Heeren T, White RF, Wolfe J, Borgos MS, Davis JD, Pepper L, Clapp R, Sutker PB, Vasterling J], et al.: Health status of Persian Gulf War veterans: self-reported symptoms, environmental exposures and the effect of stress. Int J Epidemiol 1998, 27(6): 1000-1010.

15. Steele L: Prevalence and patterns of Gulf War illness in Kansas veterans: association of symptoms with characteristics of person, place, and time of military service. Am J Epidemiol 2000, I52(10):992-1002.

16. Unwin C, Blatchley N, Coker W, Ferry S, Hotopf M, Hull L, Ismail K, Palmer I, David A, Wessely S: Health of UK servicemen who served in Persian Gulf War. Lancet 1999, 353(9 I 48): I69-178.

17. Wolfe J, Proctor SP, Erickson DJ, Heeren T, Friedman MJ, Huang MT, Sutker PB, Vasterling JJ, White RF: Relationship of psychiatric status to Gulf War veterans' health problems. Psychosom Med 1999, 6 I (4):532-540.

18. Araneta MR, Destiche DA, Schlangen KM, Merz RD, Forrester MB, Gray GC: Birth defects prevalence among infants of Persian Gulf War veterans born in Hawaii, 1989-1993. Teratology 2000, 62(4): 195-204.

19. Araneta MR, Schlangen KM, Edmonds LD, Destiche DA, Merz RD, Hobbs CA, Flood TJ, Harris JA, Krishnamurti D, Gray GC: Prevalence of birth defects among infants of Gulf War veterans in Arkansas, Arizona, California, Georgia, Hawaii, and lowa, 1989-1993. Birth Defects Res A Clin Mol Teratol 2003, 67(4):246-260.

20. Araneta MR, Kamens DR, Zau AC, Gastanaga VM, Schlangen KM, Hiliopoulos KM, Gray GC: Conception and pregnancy during the Persian Gulf War: the risk to women veterans. Ann Epidemiol 2004, I4(2): 109-116.

21. Cowan DN, DeFraites RF, Gray GC, Goldenbaum MB, Wishik SM: The risk of birth defects among children of Persian Gulf War veterans. N Engl J Med 1997, 336(23):1650-1656.

22. Doyle P, Maconochie N, Davies G, Maconochie I, Pelerin M, Prior S, Lewis S: Miscarriage, stillbirth and congenital malformation in the offspring of UK veterans of the first Gulf war. Int J Epidemiol 2004, 33(I):74-86.

23. Goss Gilroy Inc: Canadian epidemiological study of Gulf War Veterans. Ottawa: Goss Gilroy Inc; 1998.

24. Ishoy T, Andersson AM, Suadicani P, Guldager B, Appleyard M, Gyntelberg F, Skakkebaek NE: Major reproductive health characteristics in male Gulf War Veterans. The Danish Gulf War Study. Dan Med Bull 200I, 48(I):29-32.

25. Kang H, Magee C, Mahan C, Lee K, Murphy F, Jackson L, Matanoski G: Pregnancy outcomes among U.S. Gulf War veterans: a population-based survey of 30,000 veterans. Ann Epidemiol 200I, II (7):504-5II.

26. Kelsall HL, Sim MR, Ikin JF, Forbes AB, McKenzie DP, Glass DC, Ittak $P$ : Reproductive health of male Australian veterans of the I 99 I Gulf War. BMC Public Health 2007, 7:79.

27. Maconochie N, Doyle P, Davies G, Lewis S, Pelerin M, Prior S, Sampson $P$ : The study of reproductive outcome and the health of offspring of UK veterans of the Gulf war: methods and description of the study population. BMC Public Health 2003, 3:4. 
28. Maconochie N, Doyle P, Carson C: Infertility among male UK veterans of the 1990-I Gulf war: reproductive cohort study. Bmj 2004, 329(7459): I96-20I.

29. Penman AD, Tarver RS, Currier MM: No evidence of increase in birth defects and health problems among children born to Persian Gulf War Veterans in Mississippi. Mil Med 1996, 16I(I):I-6.

30. Wells TS, Wang LZ, Spooner CN, Smith TC, Hiliopoulos KM, Kamens DR, Gray GC, Sato PA: Self-reported reproductive outcomes among male and female 199I Gulf War era US military veterans. Matern Child Health J 2006, I0(6):50 I-5 I0.

31. Werler MM, Sheehan JE, Mitchell AA: Gulf War veterans and hemifacial microsomia. Birth Defects Res A Clin Mol Teratol 2005, 73(1):50-52.

32. Doyle P, Maconochie N, Ryan M: Reproductive health of Gulf War veterans. Philos Trans $R$ Soc Lond B Biol Sci 2006, 36 I ( I 468): $57 \mid-584$

33. Salamon R, Verret C, Jutand MA, Begassat M, Laoudj F, Conso F, Brochard P: Health consequences of the first Persian Gulf War on French troops. Int J Epidemiol 2006, 35(2):479-487.

34. Derogatis LR, Lipman RS, Rickels K, Uhlenhuth EH, Covi L: Hopkins symptom cheklist. In ECDEU assessment manual for psychopharmacology Edited by: Guy W. Rockville, MD: US National Institute of Health, Psychopharmacology Research Branch; 1974:575-578.

35. World Health Organisation: Manual of the International Statistical Classification of Diseases and Related Health Problems IOth Revision Geneva: World Health Organisation; 1992.

36. European Registration of Congenital Anomalies (Eurocat) Report 8: Surveillance of congenital anomalies in Europe 1980-19942002 [http://eurocat.ulster.ac.uk]. University of Ulster, Nothern Ireland

37. De Vigan C, Khoshnood B, Lhomme A, Vodovar V, Goujard J, Goffinet $F$ : [Prevalence and prenatal diagnosis of congenital malformations in the Parisian population: twenty years of surveillance by the Paris Registry of congenital malformations]. J Gynecol Obstet Biol Reprod (Paris) 2005, 34( I Pt I):8-I6.

38. Rothman KJ, Greenland S: Modern Epidemiology 2nd edition. Lippincott-Raven edition. Philadelphia; 1998.

39. Fisch H, Hyun G, Golden R, Hensle TW, Olsson CA, Liberson GL: The influence of paternal age on down syndrome. J Urol 2003 169(6):2275-2278.

40. De La Rochebrochard E, Thonneau P: Paternal age: are the risks of infecundity and miscarriage higher when the man is aged 40 years or over? Rev Epidemiol Sante Publique 2005, 53(Spec No 2):2S47-55.

4I. Moore KL, Persaud TVN: Before we are born. Essentials of Embryology and Birth Defects Philadelphia, PA: WB Saunders; 1998.

42. Presidential Advisory Committee on Gulf War Veterans' Illnesses: Final Report. 1996 [http://www.gulflink.osd.mil/gwvi/toc-f.html]. Washington, DC: US Governement Printing Office

43. Abou-Donia MB, Suliman HB, Khan WA, Abdel-Rahman AA: Testicular germ-cell apoptosis in stressed rats following combined exposure to pyridostigmine bromide, $\mathbf{N}, \mathbf{N}$-diethyl $\mathbf{m}$-toluamide (DEET), and permethrin. J Toxicol Environ Health A 2003, 66(I):57-73

44. Arfsten DP, Schaeffer DJ, Johnson EW, Robert Cunningham J, Still KR, Wilfong ER: Evaluation of the effect of implanted depleted uranium on male reproductive success, sperm concentration, and sperm velocity. Environ Res 2006, I00(2):205-2I5.

\section{Pre-publication history}

The pre-publication history for this paper can be accessed here:

http://www.biomedcentral.com/1471-2458/8/141/pre pub
Publish with Biomed Central and every scientist can read your work free of charge

"BioMed Central will be the most significant development for disseminating the results of biomedical research in our lifetime. "

Sir Paul Nurse, Cancer Research UK

Your research papers will be:

- available free of charge to the entire biomedical community

- peer reviewed and published immediately upon acceptance

- cited in PubMed and archived on PubMed Central

- yours - you keep the copyright

Submit your manuscript here:

http://www.biomedcentral.com/info/publishing_adv.asp
BioMedcentral 